\title{
Production and Characterization of Bacterial Cellulose with Different Nutrient Source and Surface-Volume Ratios
}

\section{Proizvodnja i karakterizacija bakterijske celuloze pri različitim izvorima hranjivih tvari i različitim omjerima površine i volumena}

\author{
Original scientific paper • Izvorni znanstveni rad \\ Received-prispjelo: 12. 7. 2017. \\ Accepted-prihvaćeno: 23. 5. 2018. \\ UDK: $630 * 813.13$ \\ doi:10.5552/drind.2018.1744
}

\begin{abstract}
In this research, commercially available, carrot juice was explored as alternative feedstock for production of bacterial cellulose (BC) by Gluconacetobacter hansenii (ATCC® 23769 TM). Two types of culture media were used: Hestrin-Schramm (HS) and the carrot juice medium and these culture media were incubated statically for 10 days. The effect of different volumes of media on the microbial process and the utilization of substrates by the bacteria, were also examined. The produced BC was analyzed using X-ray diffraction (XRD), scanning electron microscopy (SEM), thermogravimetric analysis (TGA), and Fourier transform infrared spectroscopy (FT-IR). The water holding capacity (WHC) did not vary greatly with $210 \mathrm{~mL}(38.6 \%), 310 \mathrm{~mL}$ (35.4\%), $360 \mathrm{~mL}(36.4 \%)$ and $410 \mathrm{~mL}$ (37.3\%) of carrot juice media, however the WHC of $310 \mathrm{~mL}$ HS media $(77.1 \%)$, actually achieved a greater WHC, compared to $410 \mathrm{~mL}$ of HS media (55.8\%). BC produced in the carrot juice media showed higher yields than cellulose produced in HS media, with values of $1.19 \mathrm{~g}, 1.35 \mathrm{~g}, 1.33 \mathrm{~g}$ and $1.21 \mathrm{~g}$ for media with 210 $m L, 310 \mathrm{~mL}, 360 \mathrm{~mL}$ and $410 \mathrm{~mL}$, respectively. According to XRD and TGA results, there were no significant differences in the crystallinity and thermal stability of cellulose produced between HS and the carrot juice medium. FT-IR of BC from HS and carrot juice medium also demonstrated a similar spectrum to alpha cellulose and microcrystalline cellulose.
\end{abstract}

Keywords: Bacterial cellulose, crystallinity, morphology, carrot, production

SAŽETAK • U radu je predstavljeno istraživanje komercijalno dostupnog soka mrkve kao alternativne sirovine za proizvodnju bakterijske celuloze (BC) uz pomoć bakterije Gluconacetobacter hansenii (ATCC 23769 TM). Primijenjene su dvije vrste medija za kulturu: Histrin-Schramm (HS) i medij od mrkvina soka te su ti mediji statički inkubirani deset dana. Istraživani su utjecaji različitih obujama medija na mikrobni proces i iskorištenje supstrata od bakterija. Dobiveni je BC analiziran s pomoću rendgenske difrakcije (XRD), skenirajuće elektronske mikroskopije (SEM), termogravimetrijske analize (TGA) i Fourierove transformirane infracrvene spektroskopije

\footnotetext{
${ }^{1}$ Authors are associate professor and MSc Engineer at Department of Forest Products Engineering, Faculty of Forestry Bartin University, Bartin, Turkey.

Autori su izvanredni profesor i magistar inženjer, zaposlenici Odjela za drvnu tehnologiju, Šumarski fakultet Sveučilišta u Bartinu, Bartin, Turska.
} 
(FT-IR). Kapacitet zadržavanja vode (WHC) nije se znatnije mijenjao pri različitom obujmu medija od mrkvina soka: pri $210 \mathrm{~mL}$ (38,6\%), $310 \mathrm{~mL}(35,4 \%), 360 \mathrm{~mL}$ (36,4\%) i $410 \mathrm{~mL}$ (37,3\%). Međutim, medij HS pri obujmu $310 \mathrm{~mL}$ (77,1\%) ostvario je veći WHC u usporedbi s obujmom od $410 \mathrm{~mL}$ (55,8\%). Proizvodnja BC-a u mediju od mrkvina soka pokazala je veće prinose od proizvodnje celuloze u mediju $H S$, s vrijednostima $1,19 \mathrm{~g}, 1,35 \mathrm{~g}$, 1,33 g i 1,21 g za obujam medija $210 \mathrm{~mL}, 310 \mathrm{~mL}, 360 \mathrm{~mL}$ i $410 \mathrm{~mL}$. Prema rezultatima XRD i TGA, nije bilo značajnih razlika u kristaliničnosti i toplinskoj stabilnosti proizvedene celuloze između medija HS $i$ mrkvina soka. FT-IR analiza BC-a proizvedenoga u mediju HS i mediju od mrkvina soka također je pokazala sličan spektar alfaceluloze i mikrokristalne celuloze.

Ključne riječi: bakterijska celuloza, kristaliničnost, morfologija, mrkva, proizvodnja

\section{INTRODUCTION \\ 1. UVOD}

Bacterial cellulose $(\mathrm{BC})$ is a bio-nanomaterial with unique properties. This material is produced by several species of bacteria. The most notable of this group is Acetobacter xylinum, renamed nowadays as Gluconacetobacter xylinus and it is found wherever the fermentation of sugars and plant carbohydrates occur (Gama et al., 2013). BC is similar to plant cellulose. However, it is purer and does not contain hemicelluloses and lignin. On the other hand, BC has higher crystallinity, degree of polymerization, water absorbing and holding capacity, mechanical strength in the wet state and stronger biological adaptability (Castro et al., 2011; Wan et al., 2007). BC has a wide application in medicine (artificial blood vessels, skin tissue repair), cosmetics, food industry (Nata de Coco) and in the production of magnetic aerogels and magnetic nano papers (Klemm et al., 2001; Olsson et al., 2010; Halib et al., 2012; Fu and Yang, 2013). Many studies were carried out to decrease the high production costs of bacterial cellulose, which is the main problem for industrial scale production. Alternative carbon sources, such as olive oil residues, molass, corn steep liquor and fruits, were used and evaluated (El-Saied et al., 2008; Gomes et al., 2013; Castro et al., 2011).

The aim of this study was to determine the ability of carrot juice media as a nutrient source in different surface-volume ratios; 15 x $20 \mathrm{~cm}-210 \mathrm{ml}$ (A), 15 x $20 \mathrm{~cm}-310 \mathrm{ml}$ (B), 15 x $20 \mathrm{~cm}-360 \mathrm{ml}(\mathrm{C})$ and $15 \mathrm{x}$ $20 \mathrm{~cm}$ - 410 (D) $\mathrm{ml}$ compared to standard Hestrin-Schramm (HS) media (KA), (KB), (KC) and (KD), respectively.

\section{MATERIALS AND METHODS 2. MATERIJALI I METODE \\ 2.1 Materials \\ 2.1. Materijali}

Gluconacetobacter hansenii strain used in this research was obtained from the American Type Culture Collection (ATCC $® 23769^{\mathrm{TM}}$ ). The seed culture was prepared according to the ATCC procedure. The main culture was started by inoculating $10 \%(\mathrm{v} / \mathrm{v})$ of the seed culture with the standard Hestrin-Schramm culture medium (Hestrin and Schramm, 1954). It was incubated at $30{ }^{\circ} \mathrm{C}$ for 7 days under stable conditions in $250 \mathrm{ml}$ Erlenmeyer flasks. Two types of culture media were used for the experiments: Carrot juice (Carrot) media; squeezed juice of $1.5 \mathrm{~kg}$ planed fresh carrots in 1/1.5 ratio with deionized water and Hestrin-Schramm (HS) media for control.

\subsection{Methods \\ 2.2. Metode}

The culture media used were sterilized at $121{ }^{\circ} \mathrm{C}$ in an autoclave for $20 \mathrm{~min}$ and poured into Erlenmeyer flasks. Experiments were prepared by adding $10 \%$ (v/v) inoculums to the Carrot and HS media in different surface-volume ratios, namely $17.5 \times 11.5 \times 1.5 \mathrm{~cm}$ $=210 \mathrm{ml}(\mathrm{A}), 17.5 \times 11.5 \times 2.0 \mathrm{~cm}=310 \mathrm{ml}(\mathrm{B}), 17.5$ $\mathrm{x} 11.5 \times 2.2 \mathrm{~cm}=360 \mathrm{ml}(\mathrm{C}), 17,5 \times 11,5 \times 2,5 \mathrm{~cm}=$ $410 \mathrm{ml}(\mathrm{D})$ and (KA), (KB), (KC) and (KD), respectively, and they were statically incubated at $30^{\circ} \mathrm{C}$ for 14 days. The collected pellicles were boiled in water for $1 \mathrm{~h}$ and treated for $12 \mathrm{~h}$ in a $0.5 \mathrm{M} \mathrm{NaOH}$ solution, rinsed overnight with tap water and followed by washing with deionized water to neutral $\mathrm{pH}$ and weighed (wet weight). Freeze dried samples were prepared after a pre-treatment for $15^{\circ} \mathrm{C}(48 \mathrm{~h})$ under $0.454 \mathrm{mBar}$ and $-55^{\circ} \mathrm{C}$ conditions and weighted (dry weight).

The water holding capacity $(W H C)$ and yield $(Y)$ were calculated as follows (Shezad et al. 2010);

$$
W H C=\frac{\begin{array}{c}
\text { Mass of water removed } \\
\text { during drying }(g)
\end{array}}{\begin{array}{c}
\text { Dry weight of } B C \\
\text { sample }(g)
\end{array}} \times 100
$$

$$
\begin{aligned}
& \text { Dry weight of } B C
\end{aligned}
$$

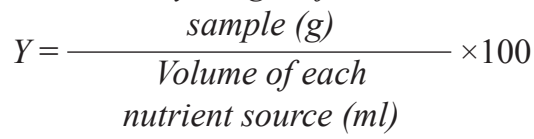

\subsubsection{Scanning electron microscopy (SEM)}

2.2.1. Skenirajuća elektronska mikroskopija (SEM)

The freeze-dried samples were coated with gold (Quorum, UK). Analysis of the BC structure was performed by using a SEM (Quanta FEG 450, Netherlands) at $5 \mathrm{kV}$. Images were taken with $50000 \times \mathrm{SEM}$ micrograph magnifications.

\subsubsection{X-Ray diffraction (XRD)}

2.2.2. Rendgenska difrakcija (XRD)

XRD was performed with a high resolution Xray diffractometer (Model Rigaku Smartlab, Made in Japan) with a Ni-filtered $\mathrm{Cu} \mathrm{K \alpha}(2 \mathrm{~kW}, \mathrm{k} \alpha: 1.54 \AA)$ radiation source operated at voltage of $40 \mathrm{kV}$ and $30 \mathrm{~mA}$. The samples were scanned from $10^{\circ}-40^{\circ} 2 \theta$ range with 
a step of $10 \%$ min. Crystallinity index (C.I.) of $\mathrm{BC}$ samples were calculated from the reflected intensity data using Segal method (Keshk, 2014; Terinte et al., 2011):

$$
C I=100 \cdot \frac{I_{020}-I_{\text {non-cr }}}{I_{020}}(\%)
$$

Where; $\mathrm{I}_{020}$ is the maximum intensity of lattice diffraction $\left(2 \theta\right.$ of $16^{\circ}$ to $\left.17^{\circ}\right)$ and $I_{\text {non-cr }}$ is that of the amorphous material between $2 \theta$ of $14^{\circ}$ to $15^{\circ}$ where the intensity is minimum.

\subsubsection{FT-IR spectroscopy \\ 2.2.3. FT-IR spektroskopija}

Fourier-Transform InfraRed (ATR-FTIR) spectroscopy analysis of the BC sample was carried out on a Shimadzu IRAffinity- One FTIR spectrometer (Japan), equipped with a Universal ATR accessory, using 200 scans and a resolution of $4 \mathrm{~cm}^{-1}$, over the range $4000-800 \mathrm{~cm}^{-1}$.

\subsubsection{Thermogravimetric analysis (TGA)}

2.2.4. Termogravimetrijska analiza (TGA)

TGA analysis was evaluated with an SII Model TG/DTA 7200 EXSTAR (Made in Japan) analyser. Each sample $(5 \mathrm{mg})$ was scanned from $30^{\circ}$ to $450^{\circ} \mathrm{C}$ at a heating rate of $10^{\circ} \mathrm{C} / \mathrm{min}$ in the presence of nitrogen with a flow rate of $20 \mathrm{ml} / \mathrm{min}$ to avoid sample oxidation.

\section{RESULTS AND DISCUSSION}

\section{REZULTATI I RASPRAVA}

Some data such as the yield, wet-dry weight values, and water holding capacity (WHC) of BC are given in Table 1, 2 and 3.

The composition of the nutrient medium, $\mathrm{pH}$, temperature and the interaction of the surface area to the volume of substrate, as well as strain activity, are the fundamental factors affecting BC production and the profitability of the biotechnological process (Krystynowicz et al., 2002; Poyrazoglu and Biyik, 2011; Ruka et al., 2012). The yield increased in CarrotBC (1.27 g/L) compared to HS-BC (0.60 g/l). The water holding capacity (WHC) is considered one of the most important physical characteristics of $\mathrm{BC}$, which is directly involved in the biomedical applications of BC as wound dressing material (Ul-Islam et al., 2012; Tsouko et al., 2015). The variations between the WHC are related to the porosity and surface area of each $\mathrm{BC}$ and it is also known that the greater the surface area and the larger the pore size, the greater will be the WHC of the BC sample (Tsouko et al., 2015). The results showed that the HS-BC absorbed 68 times its dry weight of water. The WHC decreased to 37 in Carrot$\mathrm{BC}$ medium compared to HS-BC.

Scanning electron micrographs (SEM) of freezedried Carrot-BC pellicle and of the reference medium HS-BC were evaluated. The fracture surface morphology of the Carrot-BC pellicles exhibits a slightly smaller and narrower diameter distribution in comparison with HS-BC. The SEM micrographs indicate that most of the fibers are in the range of 60 to $70 \mathrm{~nm}$ for Carrot-
Table 1 Bacterial cellulose yield (dry-basis)

Tablica 1. Prinos bakterijske celuloze (suha tvar)

\begin{tabular}{|c|c|c|c|}
\hline \multirow{2}{*}{$\begin{array}{c}\text { Volume } \\
\text { Obujam } \\
\mathrm{mL}\end{array}$} & \multicolumn{2}{|c|}{$\begin{array}{c}\text { Bacterial cellulose yield, g/l } \\
\text { Prinos bakterijske celuloze, g/l }\end{array}$} & $\begin{array}{c}\text { Differ- } \\
\text { ence }\end{array}$ \\
\cline { 2 - 3 } & $\begin{array}{c}\text { Carrot-BC } \\
\text { BC-medij od } \\
\text { mrkvina soka }\end{array}$ & $\begin{array}{c}\text { HS-BC } \\
\text { BC- medij HS }\end{array}$ & $\begin{array}{c}\text { Razlika } \\
\%\end{array}$ \\
\hline 210 & 1.19 & 0.61 & 95 \\
\hline 310 & 1.35 & 0.51 & 164 \\
\hline 360 & 1.33 & 0.63 & 111 \\
\hline 410 & 1.21 & 0.65 & 86 \\
\hline $\begin{array}{c}\text { Average } \\
\text { Prosječna } \\
\text { vrijednost }\end{array}$ & 1.27 & 0.60 & 112 \\
\hline
\end{tabular}

Table 2 BC wet - dry weight values

Tablica 2. Vrijednosti mase suhe i vlažne bakterijske celuloze

\begin{tabular}{|c|c|c|c|c|}
\hline \multirow{4}{*}{$\begin{array}{c}\text { Volume } \\
\text { Obujam } \\
\mathrm{mL}\end{array}$} & \multicolumn{2}{|c|}{$\begin{array}{c}\text { Carrot-BC } \\
\text { BC-medij od } \\
\text { mrkvina soka }\end{array}$} & \multicolumn{2}{c|}{$\begin{array}{c}\text { HS-BC } \\
\text { BC-medij HS }\end{array}$} \\
\cline { 2 - 5 } & $\begin{array}{c}\text { Wet } \\
\text { Vlažna } \\
\mathrm{g}\end{array}$ & $\begin{array}{c}\text { Dry } \\
\text { Suha } \\
\mathrm{g}\end{array}$ & $\begin{array}{c}\text { Wet } \\
\text { Vlažna } \\
\mathrm{g}\end{array}$ & $\begin{array}{c}\text { Dry } \\
\text { Suha } \\
\mathrm{g}\end{array}$ \\
\hline 210 & 9.90 & 0.25 & 9.11 & 0.13 \\
\hline 310 & 15.28 & 0.42 & 12.56 & 0.16 \\
\hline 360 & 17.93 & 0.48 & 16.06 & 0.23 \\
\hline 410 & 19.14 & 0.50 & 15.33 & 0.27 \\
\hline
\end{tabular}

Table 3 BC water holding capacity

Tablica 3. Kapacitet zadržavanja vode BC-a

\begin{tabular}{|c|c|c|}
\hline \multirow{2}{*}{$\begin{array}{c}\text { Volume } \\
\text { Obujam } \\
\mathrm{mL}\end{array}$} & \multicolumn{2}{|c|}{$\begin{array}{c}\text { Water holding capacity } \\
\text { Kapacitet zadržavanja vode, \% }\end{array}$} \\
\cline { 2 - 3 } & $\begin{array}{c}\text { Carrot-BC } \\
\text { BC- medij od } \\
\text { mrkvina soka }\end{array}$ & $\begin{array}{c}\text { HS-BC } \\
\text { BC- medij HS }\end{array}$ \\
\hline 210 & 39.60 & 69.07 \\
\hline 310 & 35.38 & 77.05 \\
\hline 360 & 36.35 & 71.17 \\
\hline 410 & 37.28 & 55.77 \\
\hline $\begin{array}{c}\text { Average } \\
\text { Prosječna vrijednost }\end{array}$ & 37.20 & 68.27 \\
\hline
\end{tabular}

$\mathrm{BC}$ and $80-100 \mathrm{~nm}$ for HS-BC pellicles. The Carrot$\mathrm{BC}$ pellicles showed much thinner and better network structure than the HS-BC pellicles (Figure 1).

Thermal stabilities of BCs obtained from different nutrition resources and surface-volume ratios were investigated by thermogravimetric analysis (TGA). According to TGA curves in Figure 2, it was observed that Carrot-BC showed lower thermal stability compared to HS-BC.

For TGA curves of the carrot-BC and HS-BC, low weight loss was detected over the temperature range of $50-200{ }^{\circ} \mathrm{C}$ because of evaporation of water bounded in the BCs, and the $T_{\text {onsets }}$ were generally found to be $265-290{ }^{\circ} \mathrm{C}$ for all BCs. According to TGA curves, all TGA results are summarized in Table 4.

As seen in Table 4, the best stability of the BCs was determined as KA. $\mathrm{T}_{10 \%}$ and $\mathrm{T}_{50 \%}$ of KA were found 

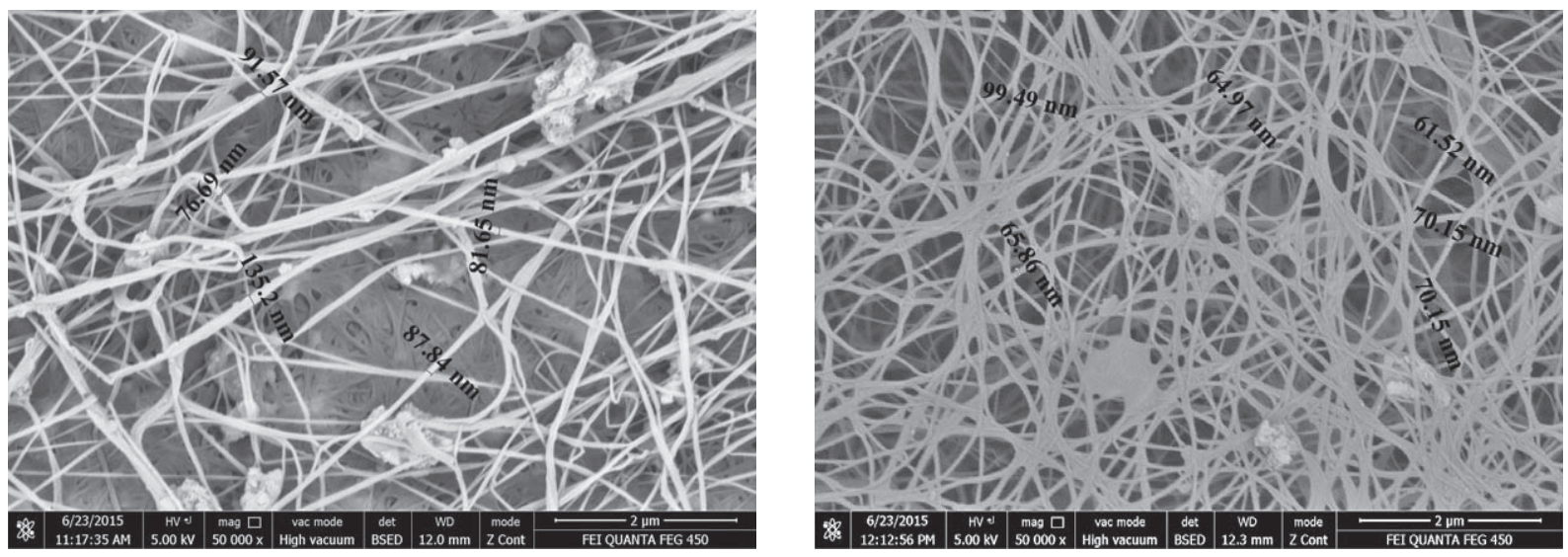

Figure 1 SEM micrographs of Carrot-BC (left) and HS-BC pellicles (right)

Slika 1. SEM mikrografije bakterijske celuloze proizvedene u mediju od mrkvina soka (lijevo) i u mediju HS (desno)
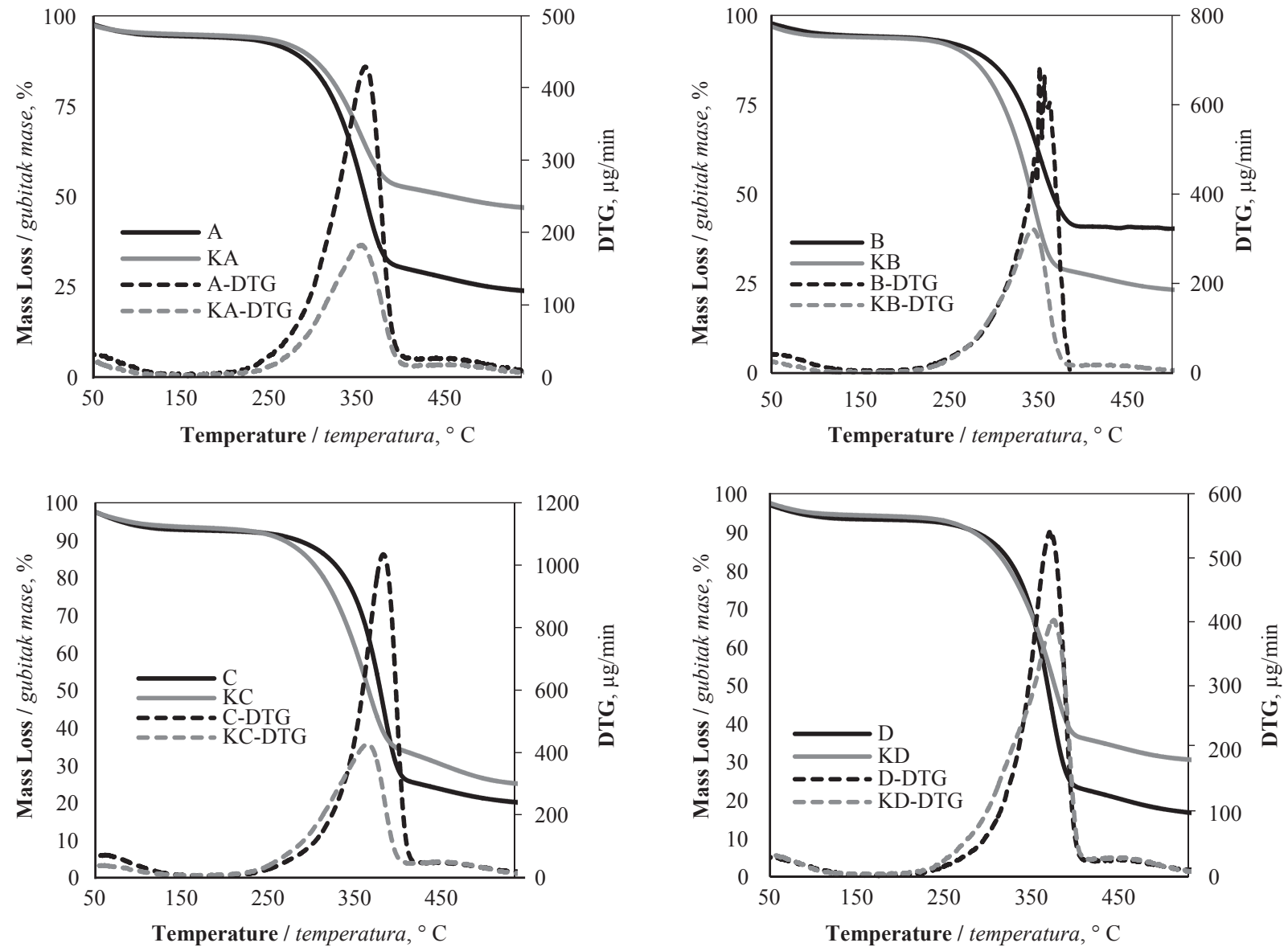

Figure 2 TGA and derivate TGA (DTG) of cellulose produced by G. hansenii from Carrot-BC (A, B, C and D) and HS-BC (KA, KB, KC and KD).

Slika 2. TGA i DTG krivulje celuloze proizvedene bakterijom $G$. hansenii u mediju od mrkvina soka (A, B, C i D) i u kontrolnom HS mediju (KA, KB, KC i KD)

as $273.2^{\circ} \mathrm{C}$ and $427.9^{\circ} \mathrm{C}$, respectively. $\mathrm{T}_{10 \%}$ and $\mathrm{T}_{50 \%}$ of the others were found to be lower than KA except for D in $\mathrm{T}_{10 \%}$. According to the weight loss, the maximum degradation was found as $83.4 \%$ for $\mathrm{H}$, and the minimum degradation was measured as $52.6 \%$ for KA. DTG curves showed maximum degradation at 354.2 ${ }^{\circ} \mathrm{C}$ for $\mathrm{F}$. As seen in TGA-DTG curves of the BCs, they exhibited three different degradation stages: (1) in the range of $50-200{ }^{\circ} \mathrm{C}$ with weight loss of small percentage $(\%)$. This mass loss may be attributed to vaporiza- tion of water; the free water is evaporated below 100 ${ }^{\circ} \mathrm{C}$, while linked water that forms physical bounds with polymers is only evaporated above $100{ }^{\circ} \mathrm{C}$. (2) in the range of $200-370{ }^{\circ} \mathrm{C}$ as a result of thermal degradation of cellulose main chains, and (3) at $370-500{ }^{\circ} \mathrm{C}$ due to thermal degradation of BCs.

The FT-IR spectra demonstrated a similar spectrum to cellulose (alpha cellulose and microcrystalline cellulose), which proved that the material produced by G. hansenii was cellulose (HS-BC). The band at 1045 
Table 4 Summarized results of TGA curves of BCs

Tablica 4. Sažeti prikaz rezultata dobivenih TGA i DTG analizom BC-a

\begin{tabular}{|c|c|c|c|c|}
\hline $\begin{array}{c}\text { BC Source } \\
\text { Izvor } B C-a\end{array}$ & $\begin{array}{c}\boldsymbol{T}_{\text {\% } 10} \\
{ }^{\circ} \mathrm{C}\end{array}$ & $\begin{array}{c}\boldsymbol{T}_{\text {\%50 }} \\
{ }^{\circ} \mathrm{C}\end{array}$ & $\begin{array}{c}\boldsymbol{D}_{\boldsymbol{T}} \boldsymbol{G}_{\text {max }} \\
{ }^{\circ} \mathrm{C}\end{array}$ & $\begin{array}{c}\text { Weight loss / Gubitak mase } \\
\text { \% }\end{array}$ \\
\hline $\mathrm{A}$ & 259.5 & 335.7 & 335.3 & 75.9 \\
\hline $\mathrm{KA}$ & 273.2 & 427.9 & 328.3 & 52.6 \\
\hline $\mathrm{D}$ & 278.6 & 366.2 & 348.2 & 64 \\
\hline $\mathrm{KE}$ & 260.8 & 330.3 & 336.2 & 87.2 \\
\hline $\mathrm{F}$ & 267.2 & 355.7 & 354.2 & 75.5 \\
\hline $\mathrm{KG}$ & 250.5 & 341.8 & 336.5 & 83.4 \\
\hline $\mathrm{H}$ & 271.5 & 348.6 & 344.3 & 69.8 \\
\hline
\end{tabular}

to $1065 \mathrm{~cm}^{-1}$ is related to $\mathrm{C}-\mathrm{O}-\mathrm{C}$ and $\mathrm{C}-\mathrm{O}-\mathrm{H}$ stretching vibration and at 1430 and $1660 \mathrm{~cm}^{-1}$ for carboxylate groups and carboxylic acid (Moosavi-Nasab and Yousefi, 2010). The bands at 2900 and 3300 to 3400 $\mathrm{cm}^{-1}$ are attributed to the $\mathrm{CH}_{2}$ stretching and the intramolecular hydrogen bonding, respectively, and the band at 3300 to $3400 \mathrm{~cm}^{-1}$ is important for elucidating hydrogen-bonding patterns (Sturcova et al., 2004). There is no significant difference between HS-BC and
Carrot-BC and the results confirmed that both $\mathrm{BC}$ samples exhibited similar chemical binding (Table 5, 6 and Figure 3).

XRD analysis of BC from Carrot-BC and HS-BC medium showed three major characteristic peaks around $2 \theta=14^{\circ}, 16^{\circ}$ and $25^{\circ}$, indicating the typical cellulose I structure. The only difference between the samples is a slight intensity change in the peaks. The crystalline indices (CI) of Carrot-BC (83\%) were also
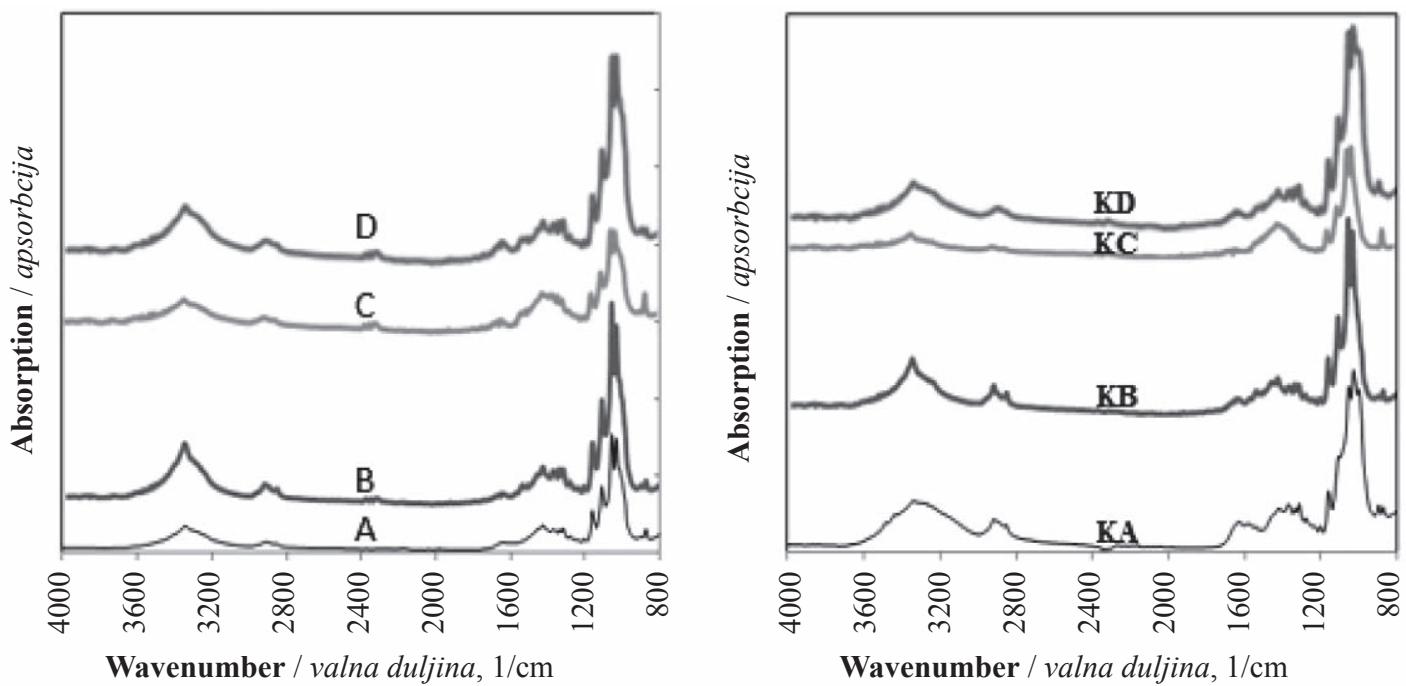

Figure 3 FT-IR spectra of cellulose produced by G. hansenii from Carrot-BC (A, B, C and D) and HS-BC (KA, KB, KC and KD) Slika 3. FT-IR spektar celuloze proizvedene bakterijom $G$. hansenii u mediju od mrkvina soka (A, B, C i D) i u kontrolnom HS mediju (KA, KB, KC i KD)

Table 5 FT-IR Spectra of Carrot-BC $\left(\mathrm{cm}^{-1}\right)$

Tablica 5. FT-IR spektar bakterijske celuloze proizvedene u mediju od mrkvina soka

\begin{tabular}{|c|c|c|c|c|c|}
\hline Analysis / Analiza & \multicolumn{5}{|c|}{ Wave Number, $\mathbf{c m}^{-1} /$ Broj valova, $\mathrm{cm}^{-1}$} \\
\hline $\mathrm{A}(210 \mathrm{ml})$ & 1031,1056 & 1107,1163 & $1315,1336,1369,1425$ & 2919 & 3342 \\
\hline $\mathrm{B}(310 \mathrm{ml})$ & 1056,1033 & 1107,1163 & $1427,1336,1315,1371$ & 2916 & 3346 \\
\hline $\mathrm{C}(360 \mathrm{ml})$ & 1053,1029 & 1109,1161 & $1315,1342,1375,1421$ & 2914 & 3346 \\
\hline $\mathrm{D}(410 \mathrm{ml})$ & 1056,1031 & 1109,1161 & $1315,1338,1369,1427$ & 2918 & 3340 \\
\hline
\end{tabular}

Table 6 FT-IR Spectra of HS-BC $\left(\mathrm{cm}^{-1}\right)$

Tablica 6. FT-IR spektar bakterijske celuloze proizvedene u mediju HS

\begin{tabular}{|c|c|c|c|c|c|}
\hline Analysis / Analiza & \multicolumn{5}{|c|}{ Wave Number, $\mathbf{c m}^{-1} /$ Broj valova, cm $^{-1}$} \\
\hline $\mathrm{KA}(210 \mathrm{ml})$ & 1028,1055 & 1107,1159 & $1315,1336,1371,1421$ & 2916 & 3336 \\
\hline $\mathrm{KB}(310 \mathrm{ml})$ & 1056,1033 & 1110,1161 & $1425,1336,1317,1361$ & 2918 & 3350 \\
\hline $\mathrm{KC}(360 \mathrm{ml})$ & 1056,1033 & 1109,1163 & $1317,1340,1369,1423$ & 2920 & 3336 \\
\hline $\mathrm{KD}(410 \mathrm{ml})$ & 1055,1031 & 1109,1161 & $1315,1336,1369,1425$ & 2895 & 3334 \\
\hline
\end{tabular}


Table 7 Crystalline indices values (\%) of different cellulose sources

Tablica 7. Vrijednosti indeksa kristaliničnosti (\%) BC-a iz različitih izvora

\begin{tabular}{|l|c|c|}
\hline Sample / Uzorak & $\begin{array}{c}\text { Crystalline indices, \% } \\
\text { Indeks kristaliničnosti, \% }\end{array}$ & $\begin{array}{c}\text { Reference } \\
\text { Izvor literature }\end{array}$ \\
\hline Bacterial Cellulose (Carrot_BC) & 83 & Study Results \\
\hline Bacterial Cellulose (HS-BC) & 84 & Study Results \\
\hline Bacterial Cellulose & 82 & (Keshk, 2014) \\
\hline Bacterial Cellulose & 75 & (Grande et al. 2009) \\
\hline Bacterial Cellulose & 79 & (Shezad et al. 2010) \\
\hline Bacterial Cellulose & 78 & (Cheng et al. 2009) \\
\hline Bacterial Cellulose & $85-93$ & (Czaja et al. 2004) \\
\hline Bacterial Cellulose & $84-89$ & (Sheykhnazari et al. 2011) \\
\hline Bacterial Cellulose & $63-81$ & (Amin et al. 2014) \\
\hline Bacterial Cellulose & $74-85$ & (Gomes et al. 2013) \\
\hline Bacterial Cellulose & 80 & (Keshk, 2014) \\
\hline Microcrystalline Cellulose & 77 & (Amin et al. 2014) \\
\hline Microcrystalline Cellulose & 79 & (Terinte et al. 2011) \\
\hline Cotton & 78 & \\
\hline
\end{tabular}
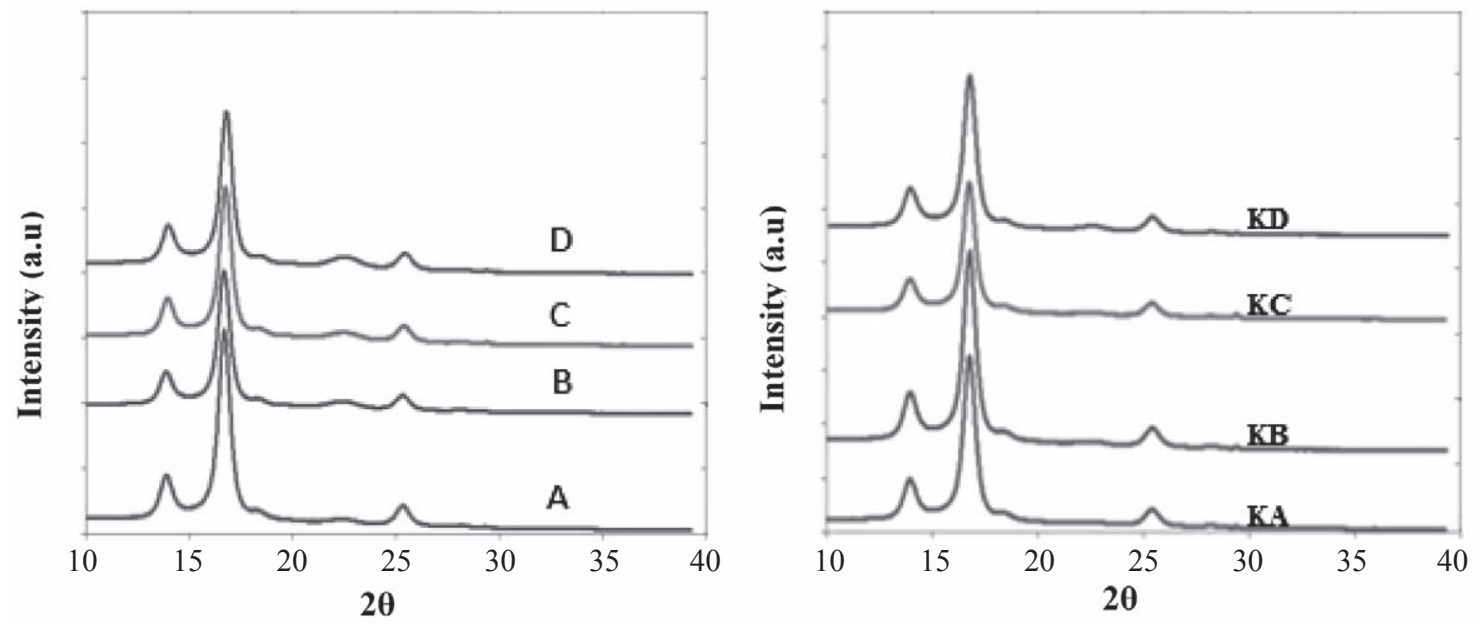

Figure 4 X-ray pattern of cellulose produced by G. hansenii from Carrot-BC (A, B, C and D) and HS-BC (KA, KB, KC and $\mathrm{KD})$.

Slika 4. Rezultati rendgenske difrakcije celuloze proizvedene bakterijom G. hansenii u mediju od mrkvina soka (A, B, C i D) i u kontrolnom HS mediju (KA, KB, KC i KD)

slightly lower than those of HS-BC (84\%) (Figure 4). Similar results were also found for the utilization of dry olive mill residues for the production of $\mathrm{BC}$ (Gomes et al., 2013). Comparison of XRD results of different cellulose structures are given in Table 7.

\section{CONCLUSIONS}

4. ZAKLJUČAK

It is generally accepted that fruits containing sufficient glucose can be used as a nutrient source for BC production. The results of this research demonstrated the possibility to produce BC in carrot juice instead from Hestrin-Schramm as a nutrient source. The fracture surface morphology of the carrot-BC medium pellicles provided a smaller cellulose fibril diameter and a better network in comparison with the $\mathrm{BC}$ pellicle from the Hestrin-Schramm medium (HS-BC). The HS-BC absorbed 68 times its dry weight of water. The WHC decreased to 37 in Carrot-BC medium compared to HS-
BC. The average yield of Carrot-BC was found to be $112 \%$ higher than that of control samples (HS-BC). The yield also increased in both media with volume ratio. The crystalline indices $(\mathrm{CI})$ of Carrot-BC $(83 \%)$ were similar to those of HS-BC $(84 \%)$. The FT-IR spectra showed no significant difference between Carrot-BC and HS-BC. The results confirmed that $\mathrm{BC}$ samples exhibited similar chemical binding. Carrot-BC showed lower thermal stability compared to HS-BC.

\section{REFERENCES}

\section{LITERATURA}

1. Amin, M. C. I. M.; Abadi, A. G.; Katas, H., 2014: Purification, characterization and comparative studies of spray-dried bacterial cellulose microparticles. Carbohydrate Polymers, 99: 180-189.

https://doi.org/10.1016/j.carbpol.2013.08.041.

2. Carreira, P.; Mendes, J. A. S.; Trovatti, E.; Serafim, L. S.; Freire, C. R. S.; Silvestre, A. J. D.; Neto, C. P., 2008: Utilization of residues from agro-forest industries in the 
production of high value bacterial cellulose. Bioresource Technology, 102: 7354-7360.

https://doi.org/10.1016/j.biortech.2011.04.081.

3. Castro, C.; Zuluaga, R.; Putaux, J. L.; Caroa, G.; Mondragon, I.; Ganán, P., 2011: Structural characterization of bacterial cellulose produced by Gluconacetobacter swingsii sp. from Colombian agro industrial wastes. Carbohydrate Polymers, 84 (1): 96-102. https://doi.org/10.1016/j.carbpol.2010.10.072.

4. Cheng, K. C.; Catchmark, J. M.; Demirci, A., 2009: Enhanced production of bacterial cellulose by using a biofilm reactor and its material property analysis. Journal of Biological Engineering, 3 (1): 12. https://doi.org/10.1186/1754-1611-3-12.

5. Czaja, W. K.; Young, D. J.; Kawecki, M.; Brown, R. M., 2007: The future prospects of microbial cellulose in biomedical applications. Biomacromolecules, 8 (1): 1-12. https://doi.org/10.1021/bm060620d.

6. El-Saied, H.; El-Diwany, A.; Basta, A. H.; Atwa, N. A.; El-Ghwas, D. N., 2008: Production and characterization of economical bacterial cellulose. BioResources, 3 (4): 1196-1217.

7. Fu, L.; Zhang, J.; Yang, G., 2013: Present status and applications of bacterial cellulose-based materials for skin tissue repair. Carbohydrate Polymers, 92: 1432-1442. https://doi.org/10.1016/j.carbpol.2012.10.071.

8. Gama, M.; Gatenholm, P.; Klemm, D.; 2013: Bacterial NanoCellulose A Sophisticated Multifunctional Material. CRC Press Taylor \& Francis Group, 304 pp.

9. Gomes, F. P.; Silva, N. H. C. S.; Trovatti, E.; Serafim, L. S.; Duarte, M. F.; Silvestre, A. J. D.; Neto, C. P.; Freire, C. S. R., 2013: Production of bacterial cellulose by Gluconacetobacter sacchari using dry olive mill residue. Biomass and Bioenergy, 55: 205-211.

https://doi.org/10.1016/j.biombioe.2013.02.004.

10. Grande, C. J.; Torres, F. G.; Gomez, C. M.; Troncoso, O. P.; Ferrer, J. C.; Pastor, J. M., 2009: Development of selfassembled bacterial cellulose-starch nanocomposites. Materials Science and Engineering C, 29: 1098-1104. https://doi.org/10.1016/j.msec.2008.09.024.

11. Halib, N.; Amin, M. C. I. M.; Ahmad, I., 2012: Physicochemical Properties and Characterization of Nata de Coco from Local Food Industries as a Source of Cellulose. Sains Malaysiana, 41 (2): 205-211.

12. Hestrin, S.; Schramm, M., 1954: Synthesis of cellulose by Acetobacter xylinum. 2. Preparation of freeze-dried cells capable of polymerizing glucose to cellulose. Biochemical Journal, 58 (2): 345. https://doi.org/10.1042/bj0580345

13. Keshk, S., 2014: Vitamin C enhances bacterial cellulose production in Gluconacetobacter xylinus. Carbohydrate Polymers, 99: 98-100. https://doi.org/10.1016/j.carbpol.2013.08.060.

14. Klemm, D.; Schumann, D.; Udhardt, U.; Marsch, S., 2001: Bacterial synthesized cellulose e artificial blood vessels for microsurgery. Prog Polym Sci., 26 (9): 15611603. https://doi.org/10.1016/S0079-6700(01)00021-1.

15. Krystynowicz, A.; Czaja. W.; Wiktorowska-Jezierska, A.; Gonçalves-Miśkiewicz, M.; Turkiewicz, M., 2002: Factors affecting the yield and properties of bacterial cellulose. Journal of Industrial Microbiology and Biotechnology, 29 (4): 189-195. https://doi:10.1038/sj.jim.7000303.

16. Moosavi-Nasab, M.; Yousefi, A. R., 2010: Investigation of physicochemical properties of the bacterial cellulose produced by Gluconacetobacter xylinus from date syrup.
World Academy of Science, Engineering \& Technology, 44:1258-1263.

17. Olsson, R. T.; Samir, A.; Salazar-Alvarez, G.; Belova, L.; Ström, V.; Berglund, L. A.; Ikkala, O.; Nogués, J.; Gedde, U. W., 2010: Making Flexible Magnetic Aerogels and Stiff Magnetic Nanopaper Using Cellulose Nanofibrils as Templates. Nature Nanotechnology, 5 (8): 584-588. https://doi:10.1038/nnano.2010.155.

18. Poyrazoglu Coban, E.; Biyik, H., 2011: Effect of various carbon and nitrogen sources on cellulose synthesis by Acetobacter lovaniensis HBB5. African Journal of Biotechnology, 10 (27): 5346-5354.

19. Ruka, D. R.; Simon, G. P.; Dean, K. M., 2012: Altering the growth conditions of Gluconacetobacter xylinus to maximize the yield of bacterial cellulose. Carbohydrate Polymers, 89: 613-622.

https://doi.org/10.1016/j.carbpol.2012.03.059.

20. Sheykhnazari, S.; Tabarsa, T.; Ashori, A.; Shakeri, A.; Golalipourd, M., 2011: Bacterial synthesized cellulose nanofibers; Effects of growth times and culture mediums on the structural characteristics. Carbohydrate Polymers, 86: $1187-1191$.

https://doi.org/10.1016/j.carbpol.2011.06.011.

21. Shezad, O.; Khan, S.; Khan, T.; Park, J. K., 2010: Physicochemical and mechanical characterization of bacterial cellulose produced with an excellent productivity in static conditions using a simple fed-batch cultivation strategy. Carbohydrate Polymers, 82: 173-180. https://doi.org/10.1016/j.carbpol.2010.04.052.

22. Sturcova, A.; His, I.; Apperley, D. C.; Sugiyama, J.; Jarvis, M. C., 2004: Structural details of crystalline cellulose from higher plants. Biomacromolecules, 5: 13331339. https://doi:10.1021/bm034517p.

23. Terinte, N.; Ibbett, R.; Schuster, K. C., 2011: Overview on native cellulose and microcrystalline cellulose I structure studied by x-ray diffraction (WAXD): comparison between measurement techniques. Lenzinger Berichte, 89: 118-131.

24. Tsouko, E.; Kourmentza, C.; Ladakis, D.; Kopsahelis, N.; Mandala, I.; Papanikolaou, S.; Paloukis, F.; Alves, V.; Koutinas, A., 2015: Bacterial cellulose production from industrial waste and by-product streams. International Journal of Molecular Sciences, 16 (7): 14832-14849. https://doi.org/10.3390/ijms160714832

25. Ul-Islam, M.; Khan, T.; Park, J. K., 2012: Water holding and release properties of bacterial cellulose obtained by in situ and ex situ modification. Carbohydrate Polymers, 88: 596-603. https://doi.org/10.1016/j.carbpol.2012.01.006.

26. Wan, Y. Z.; Huang, Y.; Yuan, C. D.; Raman, S.; Zhu, Y.; Jiang, H. J.; He, F.; Gao, C., 2007: Biomimetic synthesis of hydroxyapatite/bacterial cellulose nanocomposites for biomedical applications. Materials Science and Engineering C, 27: 855-864. https://doi.org/10.1016/j.msec.2006.10.002.

\section{Corresponding address:}

\section{Assoc. Prof. GÖKHAN GÜNDÜZ, Ph.D.}

Department of Forest Products Engineering

Faculty of Forestry Bartin University

Bartin, TURKEY

e-mail: ggunduz@bartin.edu.tr 